\title{
Maximising the use of soil water by herbaceous species in the high rainfall zone of southern Australia: a review
}

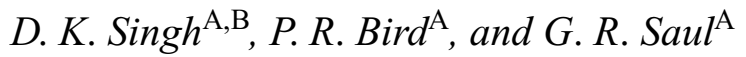 \\ ${ }^{A}$ Pastoral and Veterinary Institute, Department of Primary Industries, Hamilton, Vic. 3300, Australia. \\ ${ }^{\mathrm{B}}$ Corresponding author; current address: DPI Farming Systems Institute, Roma, QLD 4455, Australia; \\ email: Dhananjay.Singh@dpi.qld.gov.au
}

\begin{abstract}
The planting of deep-rooted pasture species, herbaceous shrubs, and trees has been widely recommended to reduce deep drainage and recharge to the groundwater in the high rainfall zone (HRZ). However, in more recent years, the value of perennial pastures to reduce recharge has been questioned in areas with $>600 \mathrm{~mm}$ annual rainfall. Currently, pastures dominated by annual species with relatively low productivity occur across much of the HRZ where deep drainage is most likely contributing to recharge. This review outlines our current understanding of water use by various herbaceous species, and indicates ways in which their water use may be increased in the HRZ of southern Australia.

To reduce deep drainage in the HRZ, the soil water deficit must be increased prior to the opening autumn rains. This will allow a greater storage of water before any potential deep drainage occurs. There are two ways that this can be achieved with the use of herbaceous species. Firstly, change to or encourage species that use more water annually. Although plants with deeper root systems including lucerne have the ability to dry the soil to depth, a combination of winter- and summer-active species, rotational grazing, and pasture spelling would extend the active growing season and soil water use of annual and perennial species. A second option is to increase the productivity of the pasture, as there is a direct link between growth and water use. For example, improving pasture productivity by $50 \%$, say from 8 to $12 \mathrm{t}$ dry matter/ha, could use (transpire) approximately $160 \mathrm{~mm}$ more water annually by a $\mathrm{C}_{3}$ species, irrespective of evaporation from the soil surface or evaporative demand factors. This is supported by strong correlations between plant dry mass and water use among a wide range of $\mathrm{C}_{3}$ and $\mathrm{C}_{4}$ plants of diverse growth form and habitat. This relationship appears to have been overlooked in recent studies of various components of the soil water balance model, possibly due to limited and unreliable estimates of evapotranspiration (ET). An improved relationship between 'estimated' ET and measured dry matter production should improve the capability of the soil water balance model to predict deep drainage, which is primarily dependent on the ET. Ways to increase pasture productivity and soil water use include regular applications of fertiliser and lime, and better management of waterlogged and acidic soils in the HRZ. Summer-active native species may also be useful on soils where the persistence of other deep-rooted perennials is poor; however, little is known about their productivity and persistence when heavily grazed.

We believe that the relationship between water use and pasture production needs to be reassessed to improve the predictability of the soil water balance approach and recommend further research in both the field and under controlled conditions to determine the potential for increased water use in the HRZ of southern Australia by combinations of plant species and greater pasture productivity.
\end{abstract}

Additional keywords: deep drainage, WUE, ET, grazing management, plant nutrition.

\begin{abstract}
Introduction
There has been an increase in deep drainage and recharge to groundwater as a consequence of tree clearing and the replacement of native grasses and shrubs by introduced pastures and crop species (Dunin 1970; Sedgley et al. 1981; McFarlane and George 1992; White et al. 2000). This is a major environmental concern, particularly in many parts of
\end{abstract}

the high rainfall zone (HRZ) of southern Australia, which receive $500-800 \mathrm{~mm}$ of rain per annum. Inefficient use of available soil water by shallow-rooted annual species has been highlighted as the primary cause for deep drainage, which in some cases can be up to $30 \%$ of annual rainfall (Ferdowsian and Greenham 1992; Simpson et al. 1998). Re-establishment of deep-rooted plants, such as perennial 
pasture species and trees, has therefore been recommended (George 1992; Williamson et al. 1997; Bolger and Turner 1999; Lefroy and Stirzaker 1999; White et al. 2000).

Increased water use by perennials, together with greater herbage production of these species, could help sustainability and productivity in the HRZ. However, changing herbaceous vegetation in the HRZ of southern Australia would have long-term effects on the hydrological cycle and livestock productivity and these effects are not clearly understood. A better understanding of soil water use and the productivity of alternative herbaceous species is needed before they are recommended for adoption in the landscape.

The primary components of the hydrological cycle in the HRZ can be well described through the soil water balance model below:

$$
\mathrm{RF}=\mathrm{I}+\mathrm{R}+\mathrm{E}+\mathrm{T}+\mathrm{L}+\Delta \mathrm{S}+\mathrm{D}
$$

where RF is rainfall, I is interception by the plant canopy and litter, $\mathrm{R}$ is surface runoff, $\mathrm{E}$ is evaporation from the soil surface, $\mathrm{T}$ is the transpiration, $\mathrm{L}$ is lateral movement from the root-zone, $\Delta \mathrm{S}$ is the change in soil water storage, and $\mathrm{D}$ is vertical drainage out of the root-zone. This review focusses on the herbaceous species and on key agro-climatic, biological, and management factors in the existing landscape (topography, soil type, and climate) of the HRZ (500-800 $\mathrm{mm}$ /year) in southern Australia.

\section{Factors influencing soil water use in the HRZ}

\section{Agro-climatic factors}

\section{Evapotranspiration}

Evapotranspiration (ET) is the sum of evaporation (E) of water from the soil surface and transpiration $(\mathrm{T})$ by the plant. ET is primarily influenced by ground cover, seasonal plant growth, and seasonal evaporative demand. Evaporative demand is a combined function of microclimatic parameters such as atmospheric temperature, leaf temperature, solar radiation, light intensity, and relative humidity. Measurement of actual ET under field conditions is highly complex; therefore, ET (actual) is mostly estimated as the potential ET or derived from the ET reference value using the modified Penman equation (Doorenbos and Pruitt 1984; Ridley et al. 1997; White et al. 2000). Large variations can occur in the estimates of ET from different methods such as the Bowen ratio method through continuous measurement of micrometeorological parameters, long-term weather data, and changes in soil water content. For a more accurate estimation of ET, inclusion of locally modified crop coefficients has been suggested (Meyer 1999).

Ward et al. (2001) and Angus and Watts (1984) reported the unreliability of the Bowen ratio method for predicting ET under conditions of low vapour flux and high available energy, particularly during the late spring and summer. Any determination of ET, either by direct measurement or estimation from weather data, carries a minimum uncertainty of at least 10\% (Angus and Watt 1984). Stewart (1984) and Gregory et al. (1992) noted that accurate measurement of ET under field conditions is very difficult and is seldom measured directly to an accuracy of $>20 \%$ with flux-gradient, ventilated chambers, or porometry. This was in agreement with other studies, and the large uncertainty associated with ET estimation, up to $20 \%$ of rainfall, can contribute significant errors to estimates of drainage (Ward et al. 1998). If the determination of ET is in error by as little as $5 \%$, deep drainage could be over or underestimated by as much as $32 \mathrm{~mm}$ per year (Murphy and Lodge 2001).

Ward et al. (2002) found no differences in ET measured by the Bowen ratio energy balance between wheat grown after lucerne (Medicago sativa) and after subterranean clover (Trifolium subterraneum), despite differences in soil water content detected by both neutron moisture meter (NMM) and time domain reflectometery (TDR). Under dry conditions, ET was estimated from changes in soil water storage using TDR and NMM (Ward et al. 2002). Dunin et al. (2001) reported that TDR records contain flawed information and adjustment was necessary to allow for an unexplained oscillation in TDR values for soil water content. They explained that systematic drifts in TDR values, both diurnally and seasonally, are likely to be due to thermal gradients occurring during drier periods. The estimation of ET through the energy balance technique is also likely to have some degree of error diurnally, due to low vapour flux, high available energy, and leaf stress in the crop canopy when transpiration demand exceeds water uptake by plant roots, particularly around midday.

\section{Rainfall}

There could be considerable differences in the rainfall actually reaching the ground in plant communities because of interception of rainfall by the canopies (Eidmann 1959; Penman 1963; Slatyer 1967). Intercepted water could be transferred to the soil through stem flow, dripping from the branches, or be lost by evaporation. Annual intercepted loss of rainfall from evergreen spruce and deciduous beech forest was $26 \%$ and $8 \%$, respectively (Eidmann 1959). However, measurement of intercepted loss and lateral flow is complex, but together can account for up to $10-40 \%$ of the annual rainfall in the HRZ (Smith 1974; White et al. 2000; Lodge et al. 2001). The amount of intercepted rainfall returned directly to the atmosphere could be up to 5 times greater than that of potential evaporation during and following rainfall (Sharma 1984; Nulsen 1993) and can account for 10-20\% of the annual rainfall (Smith 1974; Dunin and Mackay 1982; Greenwood et al. 1985). Ground cover, canopy structure, height, and litter can influence the intercepted loss, albedo values, and estimation of ET for pastures. For example, the intercepted evaporation from crop canopies was 166 and 
Table 1. Distribution of annual rainfall ( $\mathrm{RF}, \mathrm{mm}$ ) and evapotranspiration (ET, mm) in May-August in four regions of southern Australia (from Passioura and Ridley 1998)

\begin{tabular}{lcccc}
\hline Location & Annual rainfall & RF & ET & RF-ET \\
\hline Albany, WA & 808 & 436 & 148 & 288 \\
Corryong, Vic. & 825 & 325 & 111 & 214 \\
Hamilton, Vic. & 695 & 298 & 113 & 185 \\
Tamworth, NSW & 674 & 185 & 184 & 0 \\
\hline
\end{tabular}

$60 \mathrm{~mm}$ for high ground cover-herbage mass and low ground cover-herbage mass, respectively (Lodge et al. 2001). However, the amount of rainfall during summer and evaporative demand during winter are the key agro-climatic factors governing seasonal water use and biomass production by various plant species in the HRZ.

Rainfall received during autumn-winter in the HRZ of southern Australia is usually in excess of potential ET (Table 1), which is the primary cause of deep drainage and recharge. After estimating a soil water storage capacity of $135 \mathrm{~mm}$ at the beginning of winter, drainage at Hamilton was estimated to be $50 \mathrm{~mm} /$ year (Passioura and Ridley 1998).

Simpson et al. (1998) provided a different estimate of likely deep drainage at Hamilton. They predicted ET and other components of the soil water balance from modelling 20 years of data for various grazing and pasture management options (Table 2). On average, there was $484 \mathrm{~mm}$ of ET and $150 \mathrm{~mm}$ of deep drainage annually. In this study there was an estimated $130 \mathrm{~mm}$ of 'excess' rainfall at Hamilton, which the vegetation could not use even if actual transpiration were to approach potential ET. For drainage to be prevented in 'average' years at Hamilton, it was estimated that at least $1.8 \mathrm{~m}$ of soil would need to be dried to wilting point before the onset of autumn rain.

\section{Biological factors}

\section{Relationship between biomass and water use}

It is now widely accepted that regardless of any strategy, dry matter production is primarily a function of water use

Table 2. Simulated effects of various management options on average annual water balance ( $\mathrm{mm}$ ) at Hamilton 1970-90 (rainfall $639 \mathrm{~mm}$ ) (from Simpson et al. 1998)

ET, evapotranspiration; D, drainage; R, runoff

\begin{tabular}{lccc}
\hline Management option & ET & D & R \\
\hline $\begin{array}{l}\text { Annual pasture (annual grass-subterranean } \\
\text { clover), low fertility }\end{array}$ & 425 & 209 & 7 \\
$\begin{array}{l}\text { Annual pasture (annual grass-subterranean } \\
\text { clover), high fertility }\end{array}$ & 454 & 181 & 6 \\
$\begin{array}{l}\text { Perennial pasture (phalaris-subterranean } \\
\text { clover), continuous grazing }\end{array}$ & 529 & 108 & 5 \\
$\begin{array}{l}\text { Perennial pasture (phalaris-subterranean } \\
\text { clover), rotational grazing }\end{array}$ & 529 & 108 & 5 \\
$\begin{array}{l}\text { Perennial pasture (phalaris-subterranean } \\
\text { clover), complex rotational grazing with } \\
\text { pasture rested in April (1-30 Apr.) }\end{array}$ & 525 & 112 & 5 \\
\hline
\end{tabular}

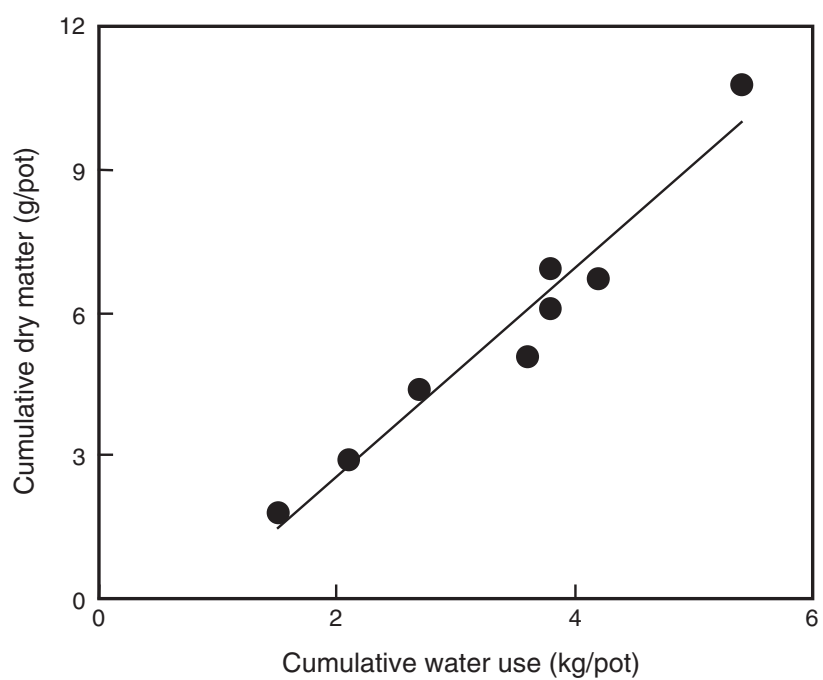

Fig. 1. Relationship between cumulative dry matter and plant water use of white clover grown under glasshouse conditions (from Singh and Sale 2000; Singh et al. 2000).

(de Wit 1958; Bierhuizen and Slatyer 1965; Tanner and Sinclair 1983). Leaf water (stomatal) conductance is correlated with photosynthetic capacity of leaves and carbon dioxide exchange for various plant species. von Caemmerer et al. (2001) showed this relationship for the $\mathrm{C}_{3}$ pasture species, subterranean clover and perennial ryegrass (Lolium perenne), grown under different environmental conditions. Ghannoum et al. (2001) highlighted the strong correlations between plant biomass and water use, and between photosynthetic capacity and stomatal conductance for $\mathrm{C}_{4}$ grasses of diverse growth, form, and habitat. Data reported by Singh and Sale (2000) and Singh et al. (2000) show a similar strong correlation between biomass production and soil water use for the $\mathrm{C}_{3}$ species white clover (Trifolium repens) across a range of fertility, defoliation, and soil water contents (Fig. 1). French (1992) and Bolger et al. (1993) also reported a positive linear relationship between water used in the growing season and pasture dry matter production at a paddock level in South Australia and Western Australia, respectively (Figs 2, 3). Singh and Misra (1985) reported that one $\mathrm{C}_{3}$ and two $\mathrm{C}_{4}$ grasses exhibited similar positive relationships across 9 treatments. Water uptake was related to plant production, despite differences in photosynthetic type, growing season, and growth stages of the grasses.

Crop water production functions further describe the relationship of crop yield response to varying levels of water input (after Liu et al. 2002). Vaux and Pruitt (1983) found the yield of various agricultural crops as a linear function of cumulative ET. However, a non-linear response may also result due to the availability of excessive water, resulting in an increased E without a corresponding increase in the yield (Vaux and Pruitt 1983; Liu et al. 2002). In contrast, Dunin (2002) suggested that there was no relationship between net 


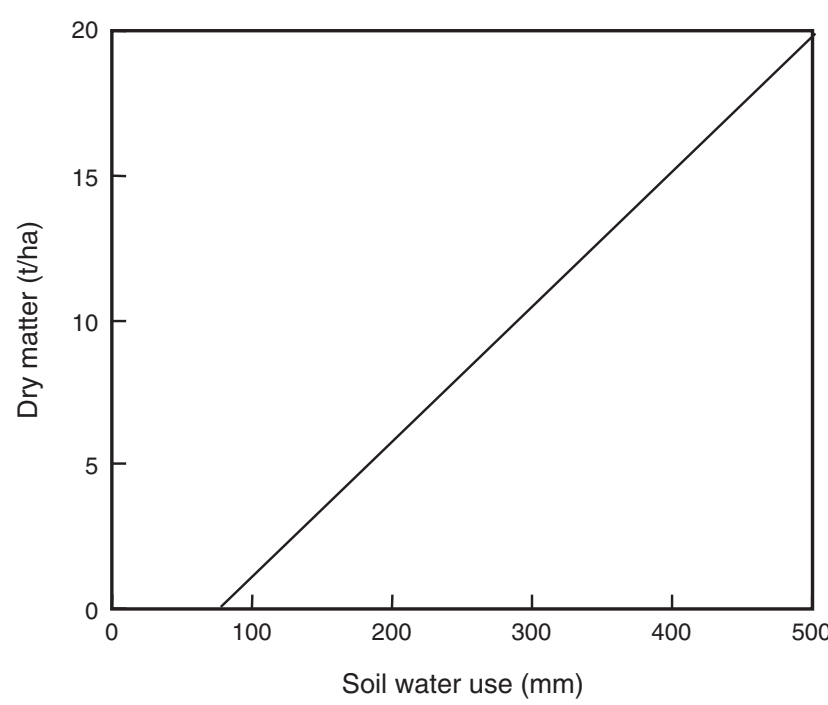

Fig. 2. Relationship between pasture dry matter and soil water use in the field in South Australia (from French 1992).

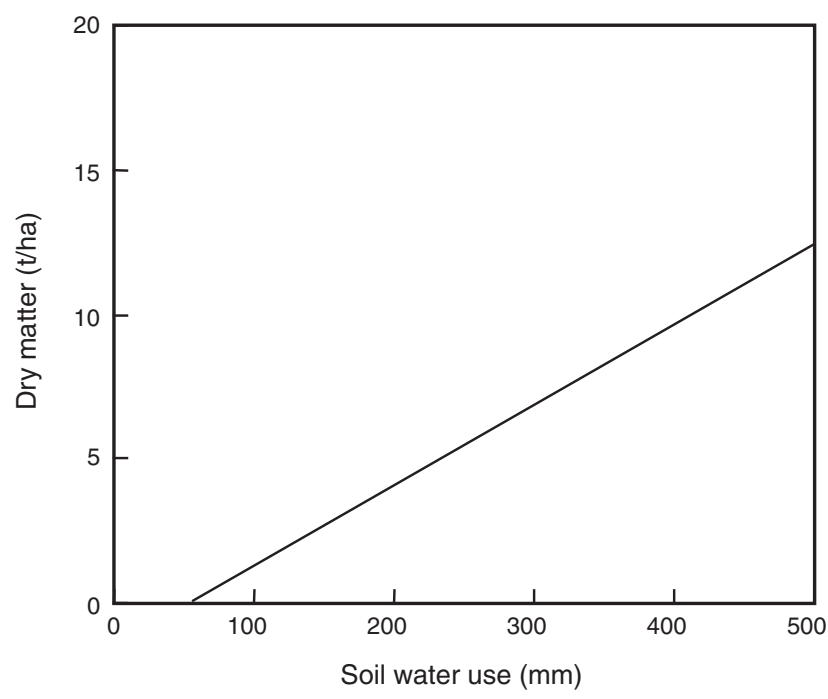

Fig. 3. Relationship between pasture dry matter and soil water use in the field in Western Australia (from Bolger et al. 1993).

primary productivity and annual water use. This conclusion was based on derived inverse relationships between maximum leaf area and water use, from comparative measurements of annual ET for tree strips, crops, subterranean clover, and lucerne, while assuming that ET follows that of Ritchie (1981) with an approximated upper boundary (ET, Priestley Taylor) without any requirement for specifying leaf canopy conditions.

Dunin (2002) argued that differences in seasonal plant water uptake and growth patterns between natural ecosystems and introduced species of crops and pastures indicated a poor relationship between primary productivity and annual water use. He suggested that the natural ecosystems conserve water during periods of high soil water availability with low evaporative demand and high water use efficiency (WUE), so that they can use this stored water in the dry periods, when water use is critical for survival of perennial species. There will be a loss in primary productivity due to the reduced WUE in the dry summer compared with winter, but the natural ecosystem with a lower LAI (leaf area per unit land area) should be able to use more stored water during summer, thus reducing deep drainage (Dunin 2002). On the other hand, although annual crops and pastures have greater productivity and LAIs than natural ecosystems, they would not be able to control deep drainage due to a lack of summer function and deep roots to utilize the excess rainfall stored below the roots-zone (Dunin 2002).

It can be suggested that productive crops and pastures with greater LAIs are more likely to use more water during the growing season in both winter- and summer-dominant rainfall regions. Consequently, less water would be stored in the soil profile compared with natural ecosystems in winter-dominant rainfall regions as suggested by Dunin (2002). Our view is strongly supported by the large amount of evidence that suggests a close relationship between productivity and water use (see previous sections). Importantly, uptake of water by any $\mathrm{C}_{3}$ or $\mathrm{C}_{4}$ plant species (whether native or exotic) is primarily governed by stomatal conductance, which is largely dependent on the photosynthetic capacity of the leaves and rates of $\mathrm{CO}_{2}$ exchange (von Caemmerer et al. 2001; Ghannoum et al. 2001) in any given condition of water availability or evaporative demand. This means that a productive species in a given environment with whatever evaporative demand would use more water than the non-productive species, whether annuals or perennials. A combination of highly productive winter- and summer-active crops and pasture species can be grown with better management practices to maximise water use, thus reducing deep drainage.

There is much evidence of drier soil profiles under natural ecosystems and well established deep-rooted perennials such as lucerne (Dunin et al. 2001; Ridley et al. 2001; Ward et al. 2001, 2002). The drier profiles under such species can be attributed to both intercepted losses of water by dense canopies and litter layers, and the drying of soil profiles by deep roots. It can be argued that intercepted losses of water are more likely to prevent greater amounts of water from entering the soil than those taken up by perennial species when there are no comparative increases in productivity. This process might further explain why soils under perennials such as lucerne have been found to be mostly dry or appear to have been rapidly dried, particularly under wet conditions, compared with continuously grazed annual pastures. This 'classic' pattern of soil drying under wet conditions can be seen in most studies, as illustrated in Fig. 4. Lightly grazed lucerne pastures with tall and dense 


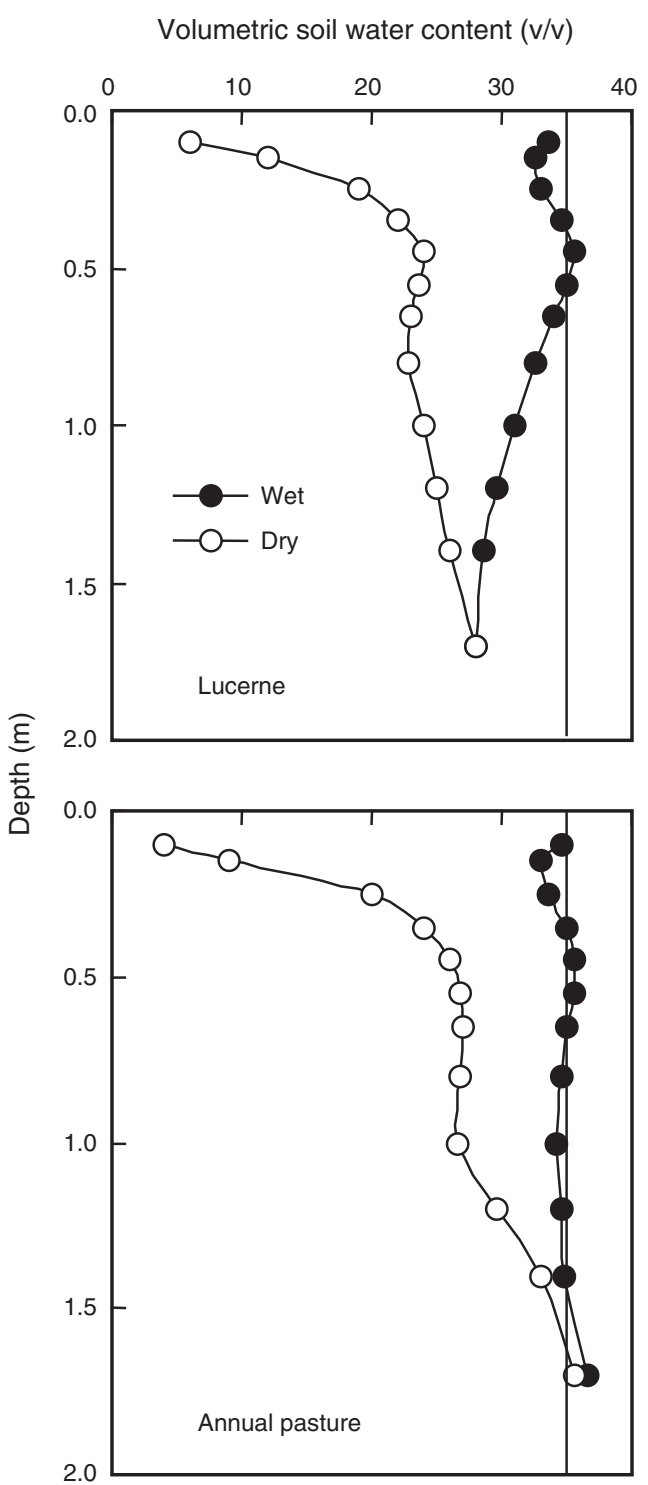

Fig. 4. Changes in soil water content with depth under lucerne and annual pasture at Tatura. Closed and open symbols refer to measurements made in winter and autumn, respectively. The vertical line indicates field capacity of the soil (from Whitfield 1996).

canopies might also intercept more water during any rainfall event. Furthermore, the perception of substantial extraction of water from below $1 \mathrm{~m}$ depth by a 'negligible' amount of deep roots may prove to be confounded, if the relationship between intercepted loss and reduced wetting of soil under these conditions could be quantified. Unfortunately, intercepted loss has been ignored in most soil water balance studies due to the complexities involved with its measurement (Ridley et al. 1997; Dunin et al. 2001; Ward et al. 2001, 2002; Dunin 2002).

The wide variations in how well the reported data describe the relationship between water use and biomass production could be largely due to variation in the estimates of ET obtained from different indirect methods such as the Bowen ratio, soil water change, long-term weather data, and simulations, compared with more reliable direct measurements from weighing lysimeters. Although Dunin et al. (2001) used weighing lysimeters and showed a close agreement between ET values obtained from lysimeters and the Bowen ratio energy balance technique through a 1:1 regression relationship, a variation of around $12 \%$ occurred within a season for a wheat crop in 1993. The regression line drawn for lucerne was based on 4 seasons of data and was in good agreement, but large variations were apparent if the relationship was drawn for each individual season, except for 1995, which involved unreplicated lysimeter values. The authors acknowledged that there were significant interruptions to the lysimeter measurements during the study period and interpolation of data from micrometeorological measurements was necessary to recover the values (Dunin et al. 2001).

Furthermore, WUEs (un-normalised) of wheat and lucerne were 3.0 and $2.0 \mathrm{~g}$ dry matter $(\mathrm{DM}) / \mathrm{kg}$ water, respectively, where the water use value (ET) included a high $(>50 \%)$ soil evaporation (Dunin et al. 2001). After accounting for the seasonal soil evaporation, further calculations indicated WUEs of $6.0 \mathrm{~g}$ and $4.0 \mathrm{~g} \mathrm{DM} / \mathrm{kg}$ of 'transpired' water, for wheat and lucerne, respectively. These values are very high compared with the range of WUEs reported for $\mathrm{C}_{3}$ plants, particularly for lucerne (Briggs and Shantz 1914; Asseng and Hsiao 2000) (see section on WUE below). An overestimated value of WUE or transpiration efficiency is more likely to result in poor correlations between water use and dry matter production and may also overestimate the deep drainage component in the soil water balance model.

\section{WUE and implications for soil water use}

The tight relationship between water use and dry matter reflects the very narrow range of WUEs. For the purpose of this review, we have defined the WUE of a plant as the amount of dry matter accumulated per unit of water 'transpired'. It has been widely used as a measure of how efficiently crops and (to a lesser extent) pastures acquire and transpire available water (Reuter et al. 1996). A greater evaporative demand or vapour pressure deficit (VPD) would decrease the boundary layer and stomatal resistances to gas exchange and increase transpiration with a reduction in WUE. VPD is primarily a difference between saturated and ambient concentrations of atmospheric water vapour. Bierhuizen and Slatyer (1965), Tanner and Sinclair (1983), and Leuning et al. (1994) reported that plant growth was directly proportional to transpirational water use, but inversely dependent on atmospheric VPD. Relative annual water requirements and plant yields for numerous $\mathrm{C}_{3}$ and $\mathrm{C}_{4}$ plants were determined earlier last century with large lysimeters, and averaged over a number of years and varieties 
Table 3. Water use efficiency (WUE, $\mathrm{g} / \mathrm{kg}$ of transpired water) of $\mathrm{C}_{3}$ and $\mathrm{C}_{4}$ plants, determined by lysimeters in field studies conducted by Briggs and Shantz (1914) at Akron, Colorado, USA, and summarised from Stanhill (1986)

\begin{tabular}{|c|c|c|c|}
\hline Plant species $\mathrm{C}_{3}$ & WUE & Plant species $\mathrm{C}_{4}$ & WUE \\
\hline Lucerne (Medicago sativa) & 1.2 & Maize (Zea mays) & 2.9 \\
\hline Red clover (Trifolium pratense) & 1.3 & Sudan grass (Sorghum sudanense) & 2.6 \\
\hline Sweet clover (Melilotus officinalis) & 1.4 & Sorghum (Sorghum bicolor) & 3.3 \\
\hline Turnip (Brassica napus) & 1.6 & Teosinte (Zea mexicana) & 2.7 \\
\hline Desert wheat grass (Agropyron desertorum) & 1.5 & Pigweed (Amaranthus alba) & 3.8 \\
\hline Smooth brome grass (Bromus inermis) & 1.0 & Russian thistle (Salsola kali) & 3.2 \\
\hline Barley (Hordeum vulgare) & 1.9 & & \\
\hline Wheat (Triticum aestivum) & 1.8 & & \\
\hline Rye (Secale cereale) & 1.6 & & \\
\hline Oats (Avena sativa) & 1.7 & & \\
\hline Rice (Oryza sativa) & 1.5 & & \\
\hline Navy bean (Phaseolus) & 1.5 & & \\
\hline Horse bean (Vicia faba) & 1.3 & & \\
\hline Soybean (Glycine max) & 1.4 & & \\
\hline Chickpea (Cicer arietinum) & 1.6 & & \\
\hline Winter vetch (Vicia vilosa) & 1.8 & & \\
\hline Lambs quarters (Chenopodium album) & 1.5 & & \\
\hline Cocklebur (Xanthium spinosum) & 2.4 & & \\
\hline Curlycup gumweed (Grindelia squarrosa) & 1.7 & & \\
\hline Sunflower (Helianthus annuus) & 1.8 & & \\
\hline
\end{tabular}

(Briggs and Shantz 1914; de Wit 1958). WUE of selected species has been summarised in Table 3 .

To compare WUE under different climatic conditions, normalisation of WUE for the evaporative demand of the atmosphere has been the preferred approach (de Wit 1958; Tanner and Sinclair 1983; Asseng and Hsiao 2000). However, the preference in evaporative demand factor, which can be expressed as pan evaporation, cumulative ET relative to the mean daily pan evaporation (de Wit 1958; Asseng and Hsiao 2000), or air vapour saturation deficit (Tanner and Sinclair 1983), can be contentious. Most studies use the mean value of the evaporative data collected during the entire crop growth period, whereas evaporative demand varies diurnally with the crop growth stage and season. Unless normalisation is done on a daily basis, evaluation and comparison of WUEs normalised with only mean values of evaporative demand are likely to be confounded (Asseng and Hsiao 2000). We have focussed on un-normalised WUEs in this review for simplicity and to avoid any confounding effect due to variation in the measurement of evaporative demand. However, it is the differences in the abilities of the plant species, such as those between $\mathrm{C}_{3}$ and $\mathrm{C}_{4}$ plants, to use soil water and produce dry matter that can be exploited by better management practices and improved soil fertility for particular climatic conditions. Both cultivar selection and nutrient management have an effect on water use by altering photosynthetic rates, yields, rooting characteristics, transpiration, and soil evaporation (Davis and Quick 1998).

The following un-normalised WUEs have been reported for lucerne: $2.3 \mathrm{~g} \mathrm{DM} / \mathrm{kg}$ water (Grimes et al. 1992), $1.8 \mathrm{~g}$
$\mathrm{DM} / \mathrm{kg}$ water (Smeal et al.1992), $1.7 \mathrm{~g} \mathrm{DM} / \mathrm{kg}$ water (Wright 1988), and $2.1 \mathrm{~g} \mathrm{DM} / \mathrm{kg}$ water (Asseng and Hsiao 2000). These values equate to requirements of $43.5-58.8 \mathrm{~mm}$ of water for each tonne of lucerne dry matter. Shih and Snyder (1984) noted that average daily ET varied from 2.0 to 7.3 $\mathrm{mm} /$ day, and $86-94 \mathrm{~mm}$ of water was required to produce each tonne of dry biomass of pasture, corresponding to a WUE of $1.1 \mathrm{~g} \mathrm{DM} / \mathrm{kg}$ water. It has been shown that an increase of $3.9 \mathrm{~g}$ cumulative dry matter yield of a $\mathrm{C}_{3}$ plant (white clover) resulted in $1.6 \mathrm{~kg}$ more water being transpired when the soil supply of phosphorus increased from 50 to 150 $\mathrm{mg} / \mathrm{kg}$ soil (Table 4). This indicates a WUE of $2.4 \mathrm{~g} \mathrm{DM} / \mathrm{kg}$ of transpired water. On average, WUE varied between 1.2 and $2.0 \mathrm{~g} \mathrm{DM} / \mathrm{kg}$ of transpired water (Table 4).

The measured range of WUEs from these studies indicates that the $\mathrm{C}_{3}$ herbaceous plant with the high WUE of $2.4 \mathrm{~g} \mathrm{DM} / \mathrm{kg}$ of transpired water will require $417 \mathrm{t}$ or 41.7 $\mathrm{mm}$ of water $(10 \mathrm{t}$ water $=1 \mathrm{~mm}$ water $)$ to produce each tonne of dry matter. Therefore, a $50 \%$ improvement in the net pasture production, say from $8 \mathrm{t}$ to $12 \mathrm{t}$, through improved agronomic practices and/or use of higher yielding varieties would use approximately $160 \mathrm{~mm}$ more water, irrespective of the water lost through soil evaporation or evaporative demand. Studies by Ridley et al. (1997) and Clifton and Taylor (1995) reported that increased yields through better agronomic management practices resulted in higher soil water use. Clifton and Taylor (1995) reported that swards of both phalaris (Phalaris aquatica) and cocksfoot (Dactylis glomerata) that were allowed to grow to higher herbage mass were able to transpire more water than swards that were kept 
Table 4. Main effect treatment means for $P$ supply $(\mathrm{mg} / \mathrm{kg}$ soil), defoliation frequency (days), and soil water regime for cumulative yield (g), cumulative water use (g), and WUE per pot (g/kg water) over 56 days (from Singh and Sale 2000; Singh et al. 2000)

\begin{tabular}{|c|c|c|c|}
\hline Treatments/rates & Cumulative yield & Cumulative water use & WUE \\
\hline \multicolumn{4}{|c|}{ P supply } \\
\hline 0 & 1.8 & 1500 & 1.2 \\
\hline 17 & 2.9 & 2071 & 1.4 \\
\hline 50 & 6.9 & 3833 & 1.8 \\
\hline 150 & 10.8 & 5400 & 2.0 \\
\hline \multicolumn{4}{|c|}{ Defoliation frequency } \\
\hline 2 & 6.7 & 4187 & 1.6 \\
\hline 4 & 4.4 & 2750 & 1.6 \\
\hline \multicolumn{4}{|c|}{ Soil water regime } \\
\hline Wet $(100-50 \%$ FC) & 6.1 & 3812 & 1.6 \\
\hline Dry $(40-0 \%$ FC) & 5.1 & 3643 & 1.4 \\
\hline
\end{tabular}

Table 5. Summary of total dry matter production ( $t / h a)$, evapotranspiration (mm/year), and WUE (g/kg water) from 1992 to 1994 for annual and perennial pastures with medium cutting height at Axe Creek (from Clifton and Taylor 1995)

\begin{tabular}{lccc}
\hline Pasture type & Dry matter & Evapotranspiration & WUE \\
\hline Phalaris & 7.77 & 525 & 1.5 \\
Cocksfoot & 6.48 & 435 & 1.5 \\
Annual & 6.61 & 395 & 1.7 \\
\hline
\end{tabular}

short. Phalaris transpired $130 \mathrm{~mm}$ more water $(33 \%$ increase) and produced $17 \%$ more dry matter than annual pasture under a medium cutting height (Table 5). Similarly, in the study of Ridley et al. (1997), the yield of phalaris $+\mathrm{N}$ treatment increased from around $8 \mathrm{t}$ to more than $16 \mathrm{t} / \mathrm{ha}$ between 1992 and 1993, despite similar pan evaporation in both years and higher April-October rainfall in 1992 (580 $\mathrm{mm}$ ) than in 1993 (368 mm). The increased yield was more likely due to increased soil fertility, as these pastures received $400 \mathrm{~kg} \mathrm{~N}$ in 1992 and $500 \mathrm{~kg} \mathrm{~N}$ in 1993. Importantly, estimated ET in 1993 was $131 \mathrm{~mm}$ higher than in 1992, indicating the influence of increased yield, rather than evaporative demand.

\section{Maximising soil water use in the HRZ}

The key agronomic and biological factors influencing soil water use in the HRZ suggest that there are two major ways of increasing plant water use: firstly, to change or encourage perennial species that use more water on an annual basis; and secondly, to increase the productivity of the existing pastures.

\section{Changing the plant species}

\section{Annual v. perennials}

Perennial pastures such as lucerne and phalaris have high water use relative to annual species, largely because they actively transpire for longer than the annuals (Nulsen 1993), and their roots are deeper. However, a survey of the botanical composition of 286 pastures across major grazing industries (dairy, sheep, and beef), rainfall zones (500-800 mm annual rainfall), and soil types (Ordovician, basalt, and mixed coastal soil) in south-western Victoria (Quigley et al. 1992) revealed a very small proportion of perennial species. Undesirable, volunteer annual grass species, especially Vulpia spp., dominated the pastures in this survey.

Deep drainage has been reported to be greater under annual than under perennial pastures in southern Australia (Ferdowsian and Greenham 1992; Whitfield et al. 1993; Ridley et al. 1997; White et al. 2000). Clifton and Johnston (1997) used a 1-dimensional model (WAVES) to estimate deep drainage for perennial and annual winter-active pastures, 228 and $314 \mathrm{~mm} /$ year, respectively. They suggested that there was minimal lateral flow for rainfall up to 900 $\mathrm{mm} /$ year. However, White et al. (2000) reported that combined lateral flow and deep drainage was $40 \mathrm{~mm}$ less for perennial pastures than for annual pastures and that, at times, lateral flow exceeded the deep drainage. They suggested that Clifton and Johnston (1997) overestimated deep drainage with the 1-dimensional model. Similarly, Ridley et al. (1997) estimated that deep drainage below $1.1 \mathrm{~m}$ depth was only 50-55 $\mathrm{mm}$ under a phalaris pasture, and $80-85 \mathrm{~mm}$ under annual ryegrass.

Lucerne, phalaris, and cocksfoot have been the most commonly studied perennial species in pasture improvement programs for HRZ (Clifton and Taylor 1995; Ridley et al. 1997; Lolicato 2000). Lucerne was the most vigorous and persistent species among 100 perennial legume cultivars, representing 45 diverse species in a 2-year study, in central Victoria (Lolicato 1993). The ability of lucerne to dry the soil to a greater depth, particularly during the spring-summer, has been highlighted by Humphries and Auricht (2001) and Ridley et al. (2001). Lolicato (2000) reported that the maximum amounts of extracted water were 
$230 \mathrm{~mm}$ by lucerne, $210 \mathrm{~mm}$ by phalaris, $200 \mathrm{~mm}$ by lotus, and $170 \mathrm{~mm}$ by cocksfoot, with the driest soils associated with greater herbage growth and greater depths of water extraction.

Ridley et al. (1997) suggested that phalaris had the highest ET, followed by cocksfoot and annual ryegrass pastures. The patterns of seasonal dry matter production and ET were similar for these 3 pasture types. Similarly, established lucerne pastures have been reported to have both increased biomass production and soil water use compared with an annual pastures, by 2 times and $51 \mathrm{~mm}$, respectively (Lyons and Latta 2001).

\section{$C_{3}$ and $C_{4}$ plants}

Potential dry matter yield and WUE are usually greater in $\mathrm{C}_{4}$ than in $\mathrm{C}_{3}$ plants because the biochemical pathways for carbon assimilation during photosynthesis are different. Tropical $\mathrm{C}_{4}$ species such as sugar cane (Saccharum officinarum), sorghum (Sorghum bicolor), maize (Zea mays), and Panicum have greater carbon assimilation rates per unit leaf area than temperate $\mathrm{C}_{3}$ species such as ryegrass, cocksfoot, and tall fescue (Festuca arundinacea). In $\mathrm{C}_{4}$ species, the internal resistance to $\mathrm{CO}_{2}$ diffusion is normally about half that in $\mathrm{C}_{3}$ species, and their stomatal resistance is generally higher (Gifford 1974; Rawson et al. 1977).

Low yielding $\mathrm{C}_{3}$ and $\mathrm{C}_{4}$ plant species have low evapotranspirational water use, due to low leaf areas as influenced by root growth, and water and nutrient supply (Schenk and Barber 1979; Faraquhar and Richards 1984). Direct comparisons between $\mathrm{C}_{4}$ (consol lovegrass) and $\mathrm{C}_{3}$ plants (phalaris and lucerne) were made for dry matter production and total water use under varying water and nutrient levels (Johnston and Shoemark 1993). Total dry matter (shoot + root) for consol lovegrass (18.2 g per pot) was twice that of Sirosa phalaris $(9.5 \mathrm{~g})$ and Pioneer lucerne $(9.8 \mathrm{~g})$, and the total water use per pot was $4.1,3.9$, and $4.3 \mathrm{~L}$ respectively. Johnston et al. (1999) indicated that summer-active $\mathrm{C}_{4}$ grasses are likely to reduce deep drainage to a greater extent than $\mathrm{C}_{3}$ grasses as they can use water during summer; this warrants further investigation in southern Australia.

Kawamitsu et al. (1987) compared $4 \mathrm{C}_{3}$ and $14 \mathrm{C}_{4}$ grass species for vapour pressure deficit (VPD), net $\mathrm{CO}_{2}$ assimilation, and leaf water conductance. Photosynthesis and transpiration were measured under different conditions of VPD and irradiance using a climate-controlled assimilation chamber. All species showed a decrease in leaf water conductance and $\mathrm{CO}_{2}$ assimilation rate with increasing VPD, but the rate of decrease of the $\mathrm{C}_{3}$ species was greater than that of the $\mathrm{C}_{4}$ species. This indicates that $\mathrm{C}_{4}$ grasses are able to use greater amounts of water under increasing VPD conditions, which are experienced during the spring and summer seasons of the HRZ.
Ghannoum et al. (2001) reported on the carbon and water economy of 17 Australian $\mathrm{C}_{4}$ grasses in a glasshouse study. Cumulative water use was strongly related to plant dry matter in both winter and summer. On average, during winter the grasses used only $20 \%$ of the water they used under summer conditions, which was associated with an $87 \%$ decrease in leaf area, relative to that grown in summer. The WUE in winter was half that achieved under summer conditions for these $\mathrm{C}_{4}$ grasses.

\section{Root activity and rooting depth}

Taylor and Clifton (1993) noted that shallow-rooted annual pastures did not take up water from below about $0.6 \mathrm{~m}$, whereas phalaris-based perennial pastures extracted water to at least $1.2 \mathrm{~m}$. Cocksfoot pasture was unable to dry the soil sufficiently to prevent saturation to $1.2 \mathrm{~m}$ by mid-August, whereas phalaris plants were more effective in drying out the soil. Similarly, White et al. (2000) reported that annual pasture extracted water to between 0.9 and $1.2 \mathrm{~m}$, whereas phalaris extracted water to $1.5 \mathrm{~m}$. Lucerne has been reported to extract soil water from below $1.5 \mathrm{~m}$ depth (Fig. 4) to about $3 \mathrm{~m}$ depth (Ridley et al. 2001). However, the roots of perennial grasses and subterranean clover grown on basalt soils occur mostly in the top $0.8 \mathrm{~m}$, with only a small proportion extending to $1.3 \mathrm{~m}$ (Clark et al. 2000).

Plants with deep tap roots should be able to dry soils to a considerable depth and survive droughts. For example, tall fescue, lucerne, and phalaris are better able to survive drought than other cool-season turf grasses such as perennial ryegrass or Kentucky blue grass (Poa pratensis) (Sheffer et al. 1987). An understanding of the anatomical and physiological mechanisms of water uptake by these species might indicate the presence of novel traits that could be incorporated into breeding programs to improve water uptake. Both intraspecific and interspecific variations in turf grass drought resistance have been attributed mainly to differences in total root density and rooting depth (Carrow 1996; Huang and Fry 1998). Roots that have greater xylem densities and diameters will have greater hydraulic conductivities, which will lead to improved water uptake, use, and tolerance to environmental stresses (Sharp and Davies 1985; Gallardo et al. 1996; Huang et al. 1997; Singh and Sale 2000).

Understanding root morphology is also critical for interpreting soil water use as a function of rooting volume and depth of rooting. Ward et al. $(2001,2002)$ reported that lucerne produced 1.7 times more root mass than subterranean clover. However, the total root mass to a depth of $2.0 \mathrm{~m}$ was less than $1.0 \mathrm{t} / \mathrm{ha}$, and there was negligible root mass below $1.0 \mathrm{~m}$ depth for both the lucerne and clover, which may have reflected the root recovery technique of washing over a $2.0-\mathrm{mm}$ sieve. This could have resulted in significant losses of fine clover roots, as more than $50 \%$ of roots could be less than $2.0 \mathrm{~mm}$ in diameter, as reported for 
white clover (Singh and Sale 2000), which has similar rooting characteristics to those of subterranean clover. This contrasts with the thicker roots of lucerne (being a tap-rooted crop), more of which would have been retained on a $2.0-\mathrm{mm}$ sieve during washing. Any comparisons between plant species with different rooting habits could be biased and ambiguous if root morphology is not considered in the techniques used to recover roots from soil. Nevertheless, it is unclear if a small proportion of deeper roots has any real effect on water use. For example, in a recent study, it was noted that the lucerne roots $>2.5 \mathrm{~m}$ deep failed to take up and use water from a subsurface watertable that was maintained at $2.5 \mathrm{~m}$ depth (Hoffmann et al. 2003).

\section{Native species}

Historically, there is evidence that native grasslands grazed by marsupials had either the capacity to use sufficient water, or the mechanisms to prevent the development of dryland salinity, before they were overgrazed and eliminated by sheep in Western Victoria (Mitchell 1838; Bride 1898; Pressland 1980). Dense tussocks of kangaroo grass (Themeda triandra) and other native species may have provided effective water-trapping features, thus reducing run off and allowing greater direct evaporation of water from the foliage. Evaporation and transpiration from a pasture in a weighing lysimeter containing 50\% kangaroo grass accounted for about $20 \%$ and $80 \%$ of the annual water loss, respectively, in a 3-year study in a subhumid region of New South Wales (Dunin and Reyenga 1978).

Dunin et al. (1999) suggested that the loss of native grasses from the basalt plains of western Victoria, as a result of overgrazing, was the reason for the appearance of secondary salinity. Garden et al. $(2000,2001)$ also noted that increasing stocking rates decreased kangaroo grass populations in NSW pastures, whereas wallaby grass (Austrodanthonia spp.) appeared to be more persistent under sheep grazing, and kangaroo grass under cattle grazing (Garden et al. 2000).

Native pastures have been generally considered to be slow in growth and not as productive as improved pastures. However, native pastures that have been fertilised, and to which legumes have been added, may be quite productive. For example, applying superphosphate to native grass pastures in Tasmania increased the carrying capacity from 2.9 to $6.0 \mathrm{DSE} /$ ha over 5 years (Friend et al. 2001). Garden et al. (2000) noted greater proportions of wallaby grass and microlaena (Microlaena stipoides) in pasture that had received more superphosphate.

Kangaroo grass pastures may be less productive than wire grass (Aristida), microlaena, and wallaby grass pasture (Garden et al. 2000). Growth rate was $19 \mathrm{~kg} \mathrm{DM} /$ ha.day for the kangaroo grass pasture, but was 35,50 , and $80 \mathrm{~kg} /$ ha.day for microlaena, wire grass, and wallaby grass respectively. The rates of growth of these latter native species were similar to those of several other exotic perennial and annual pasture species used in commercial production.

The use of native perennial species under appropriate management might be crucial in areas where the persistence of lucerne and phalaris is poor. For example, both of these introduced species establish and persist poorly in acidic soils with high levels of toxic aluminium (Crawford and Ransom 1993). The native grasses wallaby grass, microlaena, and kangaroo grass are tolerant of acidic soil conditions, including tolerance to toxic levels of aluminium and manganese (Johnston 1993); however, their use for difficult environments in southern Australia needs further investigation.

\section{Growing more pasture}

\section{Grazing management}

Grazing management is a key issue for the productivity and sustainability of pasture and livestock enterprises. The most efficient grazing system will probably involve a combination of set-stocking and some form of rotational grazing during the year, as both have advantages under certain growing conditions, and for specific feeding purposes (Saul et al. 2000). Modelling studies conducted for the Sustainable Grazing Systems project indicated that calculated drainage beneath all grazing systems was excessive and deep-rooted species, such as lucerne, will need to be included if such systems are to be sustainable (Bond et al. 1997). However, rotationally grazed or infrequently defoliated and summer-spelled pastures were more likely to dry soil profiles compared with frequently grazed pastures (Clifton et al. 1997).

It has been shown that a rotationally grazed pasture had a greater soil water deficit to $80 \mathrm{~cm}$ depth than a set-stocked pasture (Lisa Warn, pers. comm.). Rotational grazing generally favours an increased proportion of perennial grasses, compared with set stocking (Barker et al. 1991; Culvenor 2000; Virgona et al. 2000); this might translate into increased soil water use because of the greater rooting depths and longer period of active growth of the perennial grasses.

The influence of grazing management practices on soil water use and pasture production may also interact with other factors such as the growing season, availability of soil water, plant species and variety, and other agronomic factors. The effects of these interactions on the soil water use have been found to be variable, and fairly complex to understand. For example, Ward et al. $(2001,2002)$ reported that there was no difference in the estimated ET or above-ground yields between lucerne and subterranean clover pastures, despite large variations in rainfall, soil water deficits, and grazing management. The subterranean clover pasture was severely grazed, being set-stocked with 12 dry sheep equivalents (DSE)/ha, compared with the lucerne that was rotationally grazed. The lucerne was grazed for 1 week with about 
$50 \mathrm{DSE} /$ ha followed by a 6-week spell, which equates to a grazing pressure of about 7 DSE per day over 7 weeks. It was therefore not surprising that rotationally grazed lucerne was able to grow more roots and appeared to extract more water from deeper depths than the set-stocked subterranean clover (Ward et al. 2001). The repeated removal of leaf canopy with set-stocking results in a reduced photosynthate supply and translocation to the roots (Chapman et al. 1992), which in turn leads to a decline in root elongation (Chapman and Robson 1992).

Dunin et al. (2001) also reported similar ET values for wheat in 1993 and lucerne in 1995, although the wheat yielded $50 \%$ greater dry matter and had $25 \%$ greater leaf area index than the lucerne, despite a shorter growing season of approximately 8 months. Furthermore, Cox et al. (1988) reported that infrequent cutting, which led to higher yields and higher water use efficiencies than the frequent cutting, did not affect total water use or the shape of the soil water extraction profile. Sowing density influenced sward composition and the pattern of water use, but not total water use (Cox et al. 1988). The swards from the low sowing density had a lower stubble mass and tiller density, and extracted relatively more water at depths of 75 and $85 \mathrm{~cm}$ and less at depths of 15 and $35 \mathrm{~cm}$, than the swards derived from the high sowing density. The ratio of actual/potential evapotranspiration was reduced as the soil-water deficit increased and was lowest in the summer after a dry spring (Cox et al. 1988). Neither cutting height nor frequency during summer was shown to be an effective method of either conserving water or manipulating the effective rooting depth of an established sward (Cox et al. 1988). Inconsistencies in the results of these studies on grazing management and its influence on dry matter yield, soil water use, and ET are apparent, that might be due to the confounding effects of likely errors associated with the estimation of ET and/or soil water, as discussed above. Otherwise, pastures under different grazing pressures would have different defoliation stresses, heights, canopy structures, herbage masses, litter, and ground covers and so would be expected to have different net radiation, albedo values, ET and soil water use (Meyer 1999; Lodge et al. 2001).

In other physiological studies on grazing management, Singh and Misra (1985) simulated the effect of stocking rate through the use of clipping frequency when comparing the $\mathrm{C}_{3}$ winter annual Polypogon monspeliensis, the $\mathrm{C}_{4}$ perennial Dichanthium annulatum, and the $\mathrm{C}_{4}$ warm-season annual Echinochloa colona during summer and winter under different regimes of soil moisture. Leaf water status and transpiration rate decreased with increasing soil moisture stress, but the opposite effect occurred with increased clipping frequency. During winter, the transpiration rate of the $C_{4}$ perennial was much lower than that of the $C_{3}$ winter annual, as well as its own rate in summer. An increase in the transpiration rate per unit leaf area was also noted for the frequently defoliated white clover plants, but the total water use per pot was much greater for the infrequently defoliated plants due to their larger canopies (Singh et al. 2000). Asseng and Hsiao (2000) similarly reported that immediately after cutting, the total water use by lucerne through transpiration was reduced markedly, increasing to about $85 \%$ of the initial value about 3 weeks after cutting. Before cutting, the photosynthetic rate of the canopy was similar to that for other high-yielding crop species and ET was very close to the reference ET rate. These physiological studies further indicate that the frequent removal of canopy under set-stocking would result in reduced soil water use, compared with the rotationally grazed swards.

\section{Waterlogging}

Soil waterlogging during autumn and winter is a major environmental constraint to the survival of sensitive plant species in the HRZ (McDonald and Gardner 1987; Stephens and Lyons 1998). Seasonal production of pasture can be generally about $10 \%$ less on waterlogged soils than on well-drained soils (McFarlane et al.1992). The low concentration of oxygen in the rooting zone, caused by saturation or near saturation of the soil with water (Kozlowski 1984; Drew 1992; Drew et al. 1994), is the key factor in the decreased growth of waterlogging-sensitive species. For example, Rogers and Davies (1973) found that the yield of cocksfoot was most severely restrained by waterlogged conditions when compared with timothy grass (Phleum pratense), perennial ryegrass, or tall fescue. Relative yields of the 4 species varied during the season; at wet sites, timothy grass proved to be the best yielding species followed by tall fescue.

Donohue et al. (1985) reported that the cumulative yield of flooded perennial ryegrass decreased by $25 \%$ relative to the non-waterlogged control. However, the waterlogged plants partially acclimatised by growing new roots close to the soil surface as there was no difference between the effects of the shorter $(24 \mathrm{~h})$ and longer $(48 \mathrm{~h})$ periods of waterlogging. These results suggest that the drainage of surface water after irrigation is necessary to avoid significant yield losses in irrigated perennial pastures.

Rubio and Lavado (1999) reported that waterlogging significantly decreased root:shoot ratios in 2 waterloggingtolerant grasses (Paspalum dilatatum, Danthonia montevidensis). Resource partitioning within above-ground parts was less sensitive to waterlogging than partitioning between roots and shoots. Waterlogged plants allocated more resources to stems, contributing to increased plant height, and less to the submerged tissues. Watt and Haggar (1980) reported similar decreases in shoot dry weight for perennial ryegrass and fog grass (Holcus lanatus), but the plants later responded to waterlogging by producing large numbers of 
nodal roots and fine surface roots that may have enabled them to survive such conditions.

Nevertheless, where waterlogging has reduced the size of root systems or decreased the efficiency of water and nutrient uptake by roots, chlorosis, senescence, stunted growth, and death of various plant parts result (Troughton and Drew 1980; Belford 1981). Davidson et al. (1989) reviewed the adverse effects of prolonged waterlogging on the macrostructure of fragile duplex soils, denitrification, and root growth for southern Australia. However, they suggested that the deleterious effects of waterlogging can be ameliorated through the adoption of tolerant varieties, improved drainage, and agronomic practices such as raised beds, early planting, higher seeding rates, and maintenance of higher levels of nutrients using split-fertiliser applications.

\section{Soil acidity}

Acidic and acidifying soils generally occur in areas where rainfall exceeds $450 \mathrm{~mm} /$ year (Scott et al. 2000). A decrease in soil $\mathrm{pH}$ increases $\mathrm{Al}$ and $\mathrm{Mn}$ availability, and as a result, the production and persistence of most pasture species are decreased, resulting in decreased water use.

The application of lime to an acidic soil $\left(\mathrm{pH}_{\mathrm{Ca}}=4.4\right)$, high in aluminium ( $82 \mathrm{mg} / \mathrm{kg} ; \mathrm{KCl}$ extract), in south-western Victoria reduced the detrimental effect of soil acidity on pasture growth (Quigley et al. 2001). Where Al was low (26 $\mathrm{mg} / \mathrm{kg}$ ), DM production was affected by an interaction between lime and superphosphate. At lower rates of lime, DM production increased with increasing rates of superphosphate. Similarly, on dairy pastures in southern Victoria, after 5 years of lime application, soil $\mathrm{pH}$ had been increased, and soil aluminium decreased, but pasture responses were highly variable and not economic (Crawford and Gourley 2001). Scott et al. (2000) reviewed the responsiveness of subterranean clover, phalaris, lucerne, and cocksfoot to the liming of acidic soils, but the magnitude of responses varied under different conditions, with most responses occurring in the autumn-winter period. They concluded that the use of lime is the major solution to acidification if agricultural production is to continue in much of the HRZ. They also recommended sowing perennial pasture species and reduced stocking rates in a system based on native perennial pasture species.

\section{Plant nutrition}

Nutrient supply strongly affects soil water use through its effect on plant productivity. The opportunity for unused soil water to become recharge can be minimised by growing crops and pastures at their potential production levels (Nulsen 1993). Angus et al. (2001) and Dalal et al. (1998) reported that management practices that optimise crop vigour also maximise water removal by a crop and improve the WUE. Similar responses in crop growth and soil water use to improved nutrient supplies were also noted in the studies of Ridley et al. (1997) and Singh and Sale (2000). This is consistent with the close relationship between productivity and soil water use, although there are inconsistencies in the reported water-use data between fertilised and unfertilised crops. For example, despite large increases in pasture production following additional fertiliser, water use was generally similar or only slightly greater for the fertilised plots compared with control plots (Bolger and Turner 1999). Similarly, Simpson et al. (1998) (see Table 2 in this review) and Tennant and Hall (2001) reported no differences in water use by pastures fertilised with low and high rates of fertilisers.

Asseng et al. (2001) reported a minimal impact on crop transpiration when wheat crops were fertilised with nitrogen in long-term simulation studies using the Agricultural Production Systems Simulator (APSIM). In particular, they found that when the rate of nitrogen fertiliser was increased from 30 to $210 \mathrm{~kg} / \mathrm{ha}$, grain yield increased from 3.5 to $7.5 \mathrm{t} / \mathrm{ha}$, with a corresponding increase in crop transpiration of $54.5 \mathrm{~mm}$, from $63.0 \mathrm{~mm}$ to $117.5 \mathrm{~mm}$ (Asseng et al. 2001). This corresponded to an increase in WUE from 5.4 to $6.4 \mathrm{~g} / \mathrm{kg}$ of transpired water, both of which appear to be overestimates when compared with the measured values reported for $\mathrm{C}_{3}$ plants (Table 3 ). It is, though, possible to increase the WUE of $\mathrm{C}_{3}$ plants by up to $70 \%$, and $\mathrm{C}_{4}$ plants by up to $200 \%$, by modifying varieties, soil, and nutrient management practices (Singh et al. 2000; Ghannoum et al. 2001; Hatfield et al. 2001); significant increases in WUE outside the reported range of lysimeter-measured values for $\mathrm{C}_{3}$ and $\mathrm{C}_{4}$ plants would be questionable. Nevertheless, an increase in the WUE from low-fertility growing conditions to high-fertility growing conditions is mostly associated with simultaneous increases in productivity and total soil water use, although increases in the productivity are relatively greater than the increases in soil water use between the two growing conditions (Singh et al. 2000; Ghannoum et al. 2001; Hatfield et al. 2001).

On the other hand, Dalal et al. (1998), Singh and Sale (1998), Bruck et al. (2000), and Angus et al. (2001) reported increased water use and biomass production in response to enhanced plant nutrition. Bruck et al. (2000) reported that

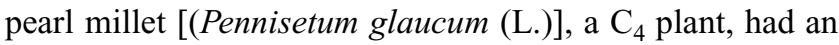
increased shoot dry matter production in response to high water and phosphate supplies. Similar increases in water uptake and WUE with increasing dry matter production were reported by Singh and Sale (1998) for white clover, a $C_{3}$ plant, in response to increased water and phosphorus supply (also see Table 4).

Although numerous studies have shown a positive relationship between soil water use and biomass production from well-managed studies in the field and under controlled conditions (Tanner and Sinclair 1983; Singh and Misra 1985; Leuning et al. 1994; Ghannoum et al. 2001), the potential to 
use this relationship to minimise deep drainage needs to be explored further under different farming systems.

\section{Conclusions}

Maximising the potential use of soil water by herbaceous species in the HRZ would be achieved in two ways. The first option is to encourage management practices that increase plant water use. Plants with deeper roots, including lucerne, phalaris, and cocksfoot, have the ability to dry the soil to depth. A combination of winter- and summer-active species, rotational grazing, and pasture spelling would also extend the active growing season and soil water use of pastures. Rotational grazing would favour the proportion of perennial grasses, relative to set-stocked pastures, which then might translate into increased soil water use due to greater rooting depths and extended growing seasons. There is a need for more work on deep-rooted native species that appear to be suited to areas of the HRZ affected by waterlogging and soil acidity. There is also a need to collect evidence on the relative abilities of native and exotic perennial pastures to control deep drainage and recharge under conditions of heavy grazing. Under light grazing, however, it is possible that dense tussocks of native species could effectively trap rainfall in their canopies, enabling greater direct evaporation of water from the soil surface and foliage. This needs to be investigated further.

The second option is to increase the productivity of existing pastures, as there is strong evidence of a direct link between growth and water use among a wide range of $\mathrm{C}_{3}$ and $\mathrm{C}_{4}$ plants of diverse growth form and habitat. This relationship appears to have been overlooked in recent studies of the various components of the soil water balance model and their effects on soil water use, although the issue has not been clarified because of limited or inaccurate field data sets for validation. In particular, the measurement of intercepted loss of water needs to be included in the soil water balance model for quantifying and predicting ET and deep drainage more accurately in future studies.

Evidence presented in this review suggests that incorporation of WUE in the soil water balance model might improve the reliability of the prediction for deep drainage, while considering the closeness of the relationship between biomass and water use and a greater reliability of the 'measured' WUE compared with the 'estimated' ET. It should also be noted that leaf water conductance is correlated with photosynthetic capacity and carbon dioxide exchange for various plant species. A significant increase in water use is more likely to be correlated with greater carbon assimilation and increased dry matter production and WUE, and vice-versa. However, further study is warranted under both controlled and field conditions to address the fundamental issue: do more productive pastures use more water?

\section{Acknowledgments}

This review was written as part of the project 'Developing on-farm options for improved management of the hydrological cycle in the HRZ' funded by the State Government of Victoria under the Science, Technology and Innovation (STI) initiative. The authors thank Anna Ridley, Kevin F. Smith, and Malcolm McCaskill for their constructive comments, and Phil Newton for sharing his experimental knowledge and understanding of soil water use in the HRZ.

\section{References}

Angus JF, Gault RR, Peoples MB, Stapper M, van Herwaarden AF (2001) Soil water extraction by dryland crops, annual pastures and lucerne in south-eastern Australia. Australian Journal of Agricultural Research 52, 183-192.

Angus JF, Watts PJ (1984) Evapotranspiration-how good is the Bowen ratio method? Agricultural Water Management 8, 133-150.

Asseng S, Dunin FX, Fillery IRP, Tennant D, Keating BA (2001) Potential deep drainage under wheat crops in a Mediterranean climate. II. Management opportunities to control drainage. Australian Journal of Agricultural Research 52, 57-66.

Asseng S, Hsiao TC (2000) Canopy $\mathrm{CO}_{2}$ assimilation, energy balance, and water use efficiency of an alfalfa crop before and after cutting. Field Crops Research 67, 191-206.

Barker DJ, Anderson CB, Dymock N (1991) 'Grasslands Wana' cocksfoot persistence and autumn/winter production in hill country, under contrasting managements and micro-topographies. New Zealand Journal of Agricultural Research 34, 25-30.

Belford RK (1981) Response of winter wheat to prolonged waterlogging under outdoor conditions. Journal of Agricultural Science 97, 557-568.

Bierhuizen JF, Slayter RO (1965) Effect of atmospheric concentration of water vapour and $\mathrm{CO}_{2}$ in determining transpiration-photosynthesis relationships of cotton leaves. Agricultural Meteorology 2, 259-270.

Bolger TP, Turner NC (1999) Water use efficiency and water use of Mediterranean annual pastures in southern Australia. Australian Journal of Agricultural Research 50, 1035-1046.

Bolger TP, Turner NC, Leach BJ (1993) Water use and productivity of annual legume-based pasture systems in the south-west of Western Australia. In 'Proceedings of XVII International Grassland Congress'. pp. 274-275. Palmerston North, New Zealand

Bond WJ, Cresswell HP, Simpson RJ, Paydar Z, Clark SG, Moore AD, Alcock DJ, Connelly JR, Freer M, Keating BA, Huth NI, Snow VO (1997) Meat Research Corporation Sustainable Grazing Systems Key Program Project SGS. 130-pre-experimentation water balance investigation. Final Report. Consultancy Report 97-31, CSIRO Land and Water, Adelaide

Bride TF (Ed.) (1898) John G Robertson, Wando Vale (Sawyers Creek, north-east of Casterton), 26 September 1853. In 'Letters from Victorian Pioneers - a series of papers on the early occupation of the colony, the aborigines, etc., addressed by Victorian pioneers to his Excellency Charles Joseph Latrobe, Lieutenant Governor of the Colony of Victoria'. [TF Bride's collection, edited by CE Sayers, 1983] pp. 154-170. (Lloyd O’Neil, Pty Ltd: South Yarra, Vic.)

Briggs LJ, Shantz HJ (1914) Relative water requirement of plants. Journal of Agricultural Research 3, 1-63.

Bruck H, Payne WA, Sattelmacher B (2000) Effects of phosphorus and water supply on yield, transpirational water-use efficiency, and carbon isotope discrimination of pearl millet. Crop Science 40, $120-125$. 
von Caemmerer S, Ghannoum O, Conroy JP, Clark H, Newton PCD (2001) Photosynthetic responses of temperate species to free air $\mathrm{CO}_{2}$ enrichment (FACE) in a grazed New Zealand pasture. Australian Journal of Plant Physiology 28, 439-450.

Carrow RN (1996) Drought resistance aspects of turfgrasses in the southeast: root-shoot responses. Crop Science 21, 43-47.

Chapman DF, Robson MJ (1992) The physiological role of stolon material in white clover (Trifolium repens L.). New Phytologist 122, 53-62.

Chapman DF, Robson MJ, Snaydon RW (1992) Interactions between defoliation and the nitrogen nutrition of white clover (Trifolium repens L.): effects on carbon utilisation in clonal plants. Plant and Soil 139, 157-167.

Clark SG, Donnelly JR, Moore AD (2000) The GrassGro decision support tool: its effectiveness in simulating pasture and animal production and value in determining research priorities. Australian Journal of Experimental Agriculture 40, 247-256.

Clifton CA, Johnston WH (1997) Perennial pastures in dryland salinity management: the role of cool and warm season grasses. In 'Groundwater in the balance. Proceedings Murray Darling 1997 Workshop'. pp. 235-240. (Department of Natural Resources: Toowoomba, Q1d)

Clifton CA, Schroder PM, Graham JF (1997) Influence of grazing management on autumn soil water deficit below perennial grass pastures. In 'Proceedings of XVIII International Grassland Conference'. pp. 61-62. (Saskatchewan Agriculture and Food: Winnipeg, Manitoba/Saskatoon, Saskatchewan, Canada)

Clifton CA, Taylor J (1995) Improving pasture management for control of dryland salinity. In 'Research note no. 8'. (Centre for Land Protection Research: Department of Conservation and Natural Resources: Bendigo, Vic.)

Cox R, Parr TW, Plant RA (1988) Water use and water use efficiency of perennial ryegrass swards as affected by the height and frequency of cutting and seed rate. Grass and Forage Science 43, 97-104.

Crawford AE, Gourley CJP (2001) Pasture responses to lime over five years are limited and highly variable. In 'Proceedings of the 10th Australian Agronomy Conference'. (The Australian Society of Agronomy: Hobart, Tas.)

Crawford MC, Ransom KP (1993) The role of lucerne in dryland salinity control. In 'A National Conference: Land management for dryland salinity control’.pp. 44-49. (La Trobe University: Bendigo, Vic.)

Culvenor RA (2000) Comparison of four phalaris cultivars under grazing: drought survival and subsequent performance under rotational grazing versus set stocking. Australian Journal of Experimental Agriculture 40, 1047-1058.

Dalal RC, Strong WM, Weston EJ, Cooper JE, Wildermuth GB, Lehane KJ, King AJ, Holmes CJ (1998) Sustaining productivity of a Vertisol at Warra, Queensland, with fertilisers, no-tillage, or legumes. 5. Wheat yields, nitrogen benefits and water use efficiency of chickpea-wheat rotation. Australian Journal of Experimental Agriculture 38, 489-501.

Davidson JL, Anderson WK, Dann PR, Gardner WK, Potter TD (1989) Environment of the high rainfall zone of southern Australia and implications for agriculture. In 'Proceedings of the 5th Australian Agronomy Conference'. pp. 67-73. (The Australian Society of Agronomy: The University of Western Australia: Perth)

Davis JG, Quick JS (1998) Nutrient management, cultivar development and selection strategies to optimize water use efficiency. Journal of Crop Production 1, 221-240.

Donohue GI, Greene RSB, Willoughby P, Wilson IB (1985) Root zone limitations to crop production on clay soil. In 'Symposium of the Australian Society of Soil Science Inc. Riverina Branch, Griffith, NSW'. (CSIRO: Melbourne)
Doorenbos J, Pruitt WO (1984) 'Guidelines for predicting crop water requirements.' FAO Drainage and Irrigation, Paper 24. (FAO: Rome)

Drew MC (1992) Soil aeration and plant root metabolism. Soil Science 154, 259-268.

Drew MC, Cobb BG, Johnson JR, Andrews D, Morgan PW, Jordan W, He CJ (1994) Metabolic acclimation of root tips to oxygen deficiency. Annals of Botany 74, 281-286.

Dunin FX (1970) Changes in water balance components with pasture management in south-eastern Australia. Journal of Hydrology 10, 90-102.

Dunin FX (2002) Integrating agroforestry and perennial pastures to mitigate water logging and secondary salinity. Agricultural Water Management 53, 259-270.

Dunin FX, Mackay SM (1982) Evaporation of eucalypt and coniferous forest communities. In 'The First National Symposium on Forest Hydrology'. (Eds EM O' Loughlin, LK Bren) pp. 18-25. (The Institution of Engineers of Australia and Australian Forestry Council: Canberra, ACT)

Dunin FX, Reyenga W (1978) Evaporation from a Themeda grassland. I. Controls imposed on the process in a sub-humid environment. Journal of Applied Ecology 15, 317-325.

Dunin FX, Smith CJ, Zegelin S, Leuning RL, Denmead OT, Poss R (2001) Water balance changes during a crop sequence with lucerne. Australian Journal of Agricultural Research 52, 247-261.

Dunin FX, Williams J, Verburg K, Keating BA (1999) Can agricultural management emulate natural ecosystems in recharge control in south-eastern Australia? Agroforestry Systems 45, 343-364.

Eidmann FE (1959) Die interception in Buchen und Fichtenbestanden. In 'Proceedings of International Association of Hydrology'. (Hannover Symposium.) Vol 1, pp. 5-25.

Faraquhar GD, Richards RR (1984) Isotopic composition of leaf carbon correlates with water use efficiency of wheat genotypes. Australian Journal of Plant Physiology 9, 121-137.

Ferdowsian R, Greenham KJ (1992) Integrated catchment management - upper Denmark catchment. Division of Resource Management, Technical Report 130, ISSN 0729-3135. Department of AGWA, Perth, WA.

French RJ (1992) Looking forward: a vision. In 'Proceedings of the 33 Annual Conference of Grassland Society of Victoria'. pp. 105-113.

Friend DA, Dolan PL, Hurst AM (2001) Superphosphate boosts productivity and profitability of native grass pastures in Tasmania. In 'Proceedings of the 10th Australian Agronomy Conference'. (The Australian Society of Agronomy: Hobart, Tas.)

Gallardo M, Jackson LE, Thompson RB (1996) Shoot and root physiological responses to localized zones of soil moisture in cultivated and wild lettuce (Lactuca spp.). Plant Cell and Environment 19, 1169-1178.

Garden DL, Dowling PM, Eddy DA, Nicol HI (2001) The influence of climate, soil, and management on the composition of native grass pastures on the central, southern, and Monaro tablelands of New South Wales. Australian Journal of Agricultural Research 52 , 925-936.

Garden DL, Lodge GM, Friend DA, Dowling PM, Orchard BA (2000) Effects of grazing management on botanical composition of native grass-based pastures in temperate south-east Australia. Australian Journal of Experimental Agriculture 40, 225-245.

George RJ (1992) Ground water processes, sand plain seeps and interactions with regional aquifer systems in South-Western Australia. Journal of Hydrology 134, 247-271.

Ghannoum O, von Caemmerer S, Conroy JP (2001) Carbon and water economy of Australian NAD-ME and NADP-ME $\mathrm{C}_{4}$ grasses. Australian Journal of Plant Physiology 28, 213-223.

Gifford RM (1974) A comparison of potential photosynthesis, productivity and yield of plant species with differing photosynthetic metabolism. Australian Journal of Plant Physiology 1, 107-117. 
Greenwood EAN, Klein L, Beresford JD, Watson JD (1985) Differences in annual evaporation between grazed pasture and eucalyptus species in plantations on a saline farm catchment. Journal of Hydrology 78, 261-278.

Gregory PJ, Tennant D, Hamblin AP, Eastham J (1992) Components of the water balance on duplex soils in Western Australia. Australian Journal of Experimental Agriculture 32, 845-854.

Grimes DW, Wiley PL, Sheesley WR (1992) Alfalfa yield and plant water relations with variable irrigation. Crop Science 32, 1381-1387.

Hatfield JL, Sauer TJ, Prueger JH (2001) Managing soils to achieve greater water use efficiency: a review. Agronomy Journal 93, 271-280.

Hoffmann JD, Eberbach PL, Virgona JA, Katupitiya A (2003) Conservative water use by lucerne. In 'Proceedings of the 11th Australian Agronomy Conference'. (The Australian Society of Agronomy: Geelong, Vic.)

Huang B, Ducan RR, Carrow RN (1997) Drought-resistance mechanisms of seven warm-season turfgrasses under surface soil drying: II. Root aspects. Crop Science 37, 1863-1869.

Huang B, Fry JD (1998) Root anatomical, morphological and physiological responses to drought stress for tall fescue cultivars. Crop Science 38, 1017-1022.

Humphries AW, Auricht GC (2001) Breeding lucerne for Australia's southern dryland cropping environments. Australian Journal of Agricultural Research 52, 183-192.

Johnston WH (1993) Water use issues in temperate agriculture-a review. In 'A National Conference: land management for dryland salinity control'. pp. 32-43. (La Trobe University: Bendigo, Vic.)

Johnston WH, Clifton CA, Cole IA, Koen TB, Mitchell ML, Waterhouse DP (1999) Low input grasses useful in limiting environments (LIGULE). Australian Journal of Agricultural Research 50, 29-53.

Johnston WH, Shoemark VF (1993) Water use of summer active grasses, lucerne and phalaris - a glasshouse study. In 'A National Conference: land management for dryland salinity control'. pp. 222-225. (La Trobe University: Bendigo, Vic.)

Kawamitsu Y, Agata W, Miura S (1987) Effects of vapour pressure difference on $\mathrm{CO}_{2}$ assimilation rate, leaf conductance and WUE in grass species. Journal of the Faculty of Agriculture 31, 1-10 (Kyushu University: Japan)

Kozlowski TT (1984) 'Flooding and plant growth.' (Academic Press: Orlando, FL)

Lefroy EC, Stirzaker RJ (1999) Agroforestry for water management in the cropping zone of southern Australia. Agroforestry Systems 45, 277-302.

Leuning R, Condon AG, Dunin FX, Zegelin S, Denmead OT (1994). Rainfall interception and evaporation from soil below a wheat canopy. Agriculture Forestry Meteorology 67, 2212-2238.

Liu WZ, Hunsaker DJ, Li YS, Xie XQ, Wall GW (2002) Interrelations of yield, evapotranspiration, and water use efficiency from marginal analysis of water production functions. Agricultural Water Management 56, 143-151.

Lodge GM, Murphy SR, Johnson IR (2001) Soil water balance modelling highlights limitations for pasture production in northern NSW. In 'Proceedings of 10th Australian Agronomy Conference'. (The Australian Society of Agronomy: Hobart, Tas.)

Lolicato SJ (1993) Plant selection of cocksfoot and perennial pasture legumes for high recharge hill sites. In 'A National Conference: land management for dryland salinity control'. pp. 231-232. (La Trobe University: Bendigo, Vic.)

Lolicato SJ (2000) Soil water dynamics and growth of perennial pasture species for dryland salinity control. Australian Journal of Experimental Agriculture 40, 37-45.
Lyons AM, Latta RA (2001) Comparing newly established lucerne with annual pastures in south-east Western Australia. In 'Proceedings of 10th Australian Agronomy Conference'. (The Australian Society of Agronomy: Hobart, Tas.)

McDonald GK, Gardner WK (1987) Effect of waterlogging on the grain yield response of wheat to sowing date in south-western Victoria. Australian Journal of Experimental Agriculture 27, 661-670.

McFarlane DJ, George RJ (1992) Factors affecting dryland salinity in two wheatbelt catchments in Western Australia. Australian Journal of Soil Research 30, 85-100.

McFarlane DJ, Wheaton GA, Negus TR, Wallace MJ (1992) Effects of waterlogging on crop and pasture production in the Upper Great Southern, Western Australia. Technical Bulletin No. 86. Department of Western Australia.

Meyer WS (1999) Standard reference evaporation calculation for inland, south-eastern Australia. CSIRO Land and Water, Adelaide Laboratory Technical Report 35/98.

Mitchell TL (1838) 'Three expeditions into the interior of eastern Australia.' Facsimile 1965. (T\&W Boone: London)

Murphy SR, Lodge GM (2001) Plant density, litter and bare soil effects on actual evaporation and transpiration in autumn. In 'Proceedings of the 10th Australian Agronomy Conference'. (The Australian Society of Agronomy: Hobart, Tas.)

Nulsen RA (1993) Opportunities and limitations for using agronomic techniques to control dryland salinity. In 'Proceedings of a National Conference: Land Management for Dryland Salinity Control'. pp. 24-31. (La Trobe University: Bendigo, Vic.)

Passioura JB, Ridley AM (1998) Managing soil water and nitrogen to minimise land degradation. In 'Proceedings of the 9th Australian Agronomy Conference'. pp. 99-106. (The Australian Society of Agronomy: Wagga Wagga, NSW)

Penman HL (1963) 'Vegetation and hydrology.' (Commonwealth Agricultural Bureaux: Farnham Royal, England)

Pressland AJ (Ed.) (1980) 'Journals of G. A. Robinson, May to August 1841.' Records of the Victorian Archaeological Survey No. 11.

Quigley PE, Schroder PM, Cameron FJ (2001) Impacts of surface-applied lime on sheep production systems in south-western Victoria. In 'Proceedings of the 10th Australian Agronomy Conference'. (The Australian Society of Agronomy: Hobart, Tas.)

Quigley PE, Ward GN, Morgan T (1992) Botanical composition of pastures in south-western Victoria. In 'Proceedings of 6th Australian Society of Agronomy Conference'. p. 533. (The Australian Society of Agronomy: Armidale, NSW)

Rawson HM, Begg JE, Woodward RG (1977) The effect of atmospheric humidity on photosynthesis, transpiration and water use efficiency of leaves of several plant species. Planta 134, 5-10.

Reuter DJ, Moore AD, Khanna PK, Tennant D, McLean GD, French RJ, Hingston FJ (1996) Indicators of farm productivity and financial performance. In 'Indicators of catchment health: a technical perspective'. (Eds J Walker, DJ Reuter) pp. 47-66. (CSIRO: Melbourne)

Ridley AM, Christy B, Dunin FX, Haines PJ, Wilson KF, Ellington A (2001) Lucerne in crop rotations on the Riverine Plains. I. The soil water balance. Australian Journal of Agricultural Research 52, 263-277.

Ridley AM, White RE, Simpson RJ, Callinan L (1997) Water use and drainage under phalaris, cocksfoot and annual ryegrass pastures. Australian Journal of Agricultural Research 48, 1011-1023.

Ritchie JT (1981) Water dynamics in the soil-plant-atmosphere system. Plant and Soil 58, 81-96.

Rogers JA, Davies GE (1973) The growth and chemical composition of four grass species in relation to soil moisture and aeration factors. Journal of Ecology 61, 455-472. 
Rubio G, Lavado RS (1999) Acquisition and allocation of resources in two waterlogging-tolerant grasses. New Phytologist 143, 539-546.

Saul G, Quigley P, Graham J, Chapman D (2000) Grazing methods for productivity and sustainability in temperate Australia. In 'BGS Occasional Symposium No. 34-grazing management'. (Eds AJ Rook, PD Penning) pp. 227-232. (British Grassland Society: Harrogate, England)

Schenk MK, Barber SA (1979) Root characteristics of corn genotypes as related to P uptake. Agronomy Journal 71, 922-924.

Scott BJ, Ridley AM, Conyers MK (2000) Management of soil acidity in long-term pastures of south-eastern Australia: a review Australian Journal of Experimental Agricultural 40, 1173-1198.

Sedgley RH, Smith RE, Tennant D (1981) Management of soil water budgets of recharge areas for control of salinity in south-western Australia. Agricultural Water Management 4, 313-334.

Sharma ML (1984) Evapotranspiration from eucalyptus community. Agricultural Water Management 8, 41-56.

Sharp RE, Davies WJ (1985) Root growth and water uptake by maize plants in drying soil. Journal of Experimental Botany 36, 1441-1456.

Sheffer KM, Dunn JH, Minner DD (1987) Summer drought response and rooting depth of three cool-season turfgrasses. Horticulture Science 22, 296-297.

Shih SF, Snyder GH (1984) Evapotranspiration, water use efficiency and water table studies of pasture. In 'Paper, American Society of Agricultural Engineers, No. 84:2013'. 19 pp. (CABI)

Simpson RJ, Bond WJ, Cresswell HP, Paydar Z, Clark SG, Moore AD, Alcock DJ, Donnelly JR, Freer M, Keating BA, Huth NI, Snow VO (1998) A strategic assessment of sustainability of grazed pasture systems in terms of their water balance. In 'Proceedings of the 9th Australian Agronomy Conference'. pp. 239-242. (The Australian Society of Agronomy: Wagga Wagga, NSW)

Singh DK, Sale PWG (1998) Phosphorus supply and the growth of frequently defoliated white clover (Trifolium repens L.) in dry soil. Plant and Soil 205, 155-168.

Singh DK, Sale PWG (2000) Growth and potential conductivity of white clover roots in dry soil with increasing phosphorus supply and defoliation frequency. Agronomy Journal 92, 868-874.

Singh DK, Sale PWG, Pallaghy CK, McKenzie BM (2000) Phosphorus concentrations in the leaves of defoliated white clover affect abscisic acid formation and transpiration in drying soil. New Phytologist 146, 249-259.

Singh KP, Misra G (1985) Water use efficiency of one $\mathrm{C}_{3}$ and two $\mathrm{C}_{4}$ grasses in response to varying soil moisture and herbage-removal levels in a seasonally dry tropical region. Plant and Soil 88, $171-180$.

Slatyer RO (1967) 'Plant-water relationship.' (CSIRO: Canberra; Academic Press: London and New York)

Smeal D, Gregory EJ, Arnold RN (1992) Interseasonal variability in the water use-production function of alfalfa. Journal of Production Agriculture 5, 576-580.

Smith MK (1974) Throughfall stemflow and interception in pine and eucalypt forest. Australian Forestry 36, 190-197.

Stanhill G (1986) Water use efficiency. Advances in Agronomy 39 53-85.

Stephens DJ, Lyons TJ (1998) Rainfall-yield relationships across the Australian wheatbelt. Australian Journal of Agricultural Research 49, 211-233.

Stewart JB (1984) Measurement and prediction of evaporation from forested and agricultural catchments. In 'Evaporation from plant communities'. (Ed. ML Sharma) pp. 1-28. (Elsevier: Amsterdam)
Tanner CB, Sinclair TR (1983) Efficient water use in crop production: research or research? In 'Limitations to efficient water use in crop production’. (Eds HM Taylor, WR Jordan, TR Sinclair) pp. 1-28. (ASA: Madison, WI)

Taylor JM, Clifton CA (1993) Recharge control in hill country - can perennial pastures do the job. In 'A National Conference: land management of dryland salinity control'. pp. 68-76. (Latrobe University: Bendigo, Vic.)

Tennant D, Hall D (2001) Improving water use of annual crops and pastures-limitations and opportunities in Western Australia. Australian Journal of Agricultural Research 52, 171-182.

Troughton MCT, Drew MC (1980) The development of waterlogging damage in young wheat plants in anaerobic solution cultures Journal of Experimental Botany 31, 1573-1585.

Vaux HJ Jr, Pruitt WO (1983) Crop-water production functions. In 'Advances in irrigation'. Vol. 2. (Ed. D Hillel) pp. 61-97. (Academic Press: New York)

Virgona JM, Avery AL, Graham JF, Orchard BA (2000) Effects of grazing management on phalaris herbage mass and persistence in summer-dry environments. Australian Journal of Experimental Agriculture 40, 171-184.

Ward PR, Dunin FX, Micin SF (2001) Water balance of annual and perennial pastures on a duplex soil in a Mediterranean environment. Australian Journal of Agricultural Research 52, 203-209.

Ward PR, Dunin FX, Micin SF (2002) Water use and root growth by annual and perennial pastures and subsequent crops in a phase rotation. Agricultural Water Management 53, 83-87.

Ward PR, Dunin FX, Micin SF, Williamson DR (1998) Evaluating drainage responses in duplex soils in a Mediterranean environment. Australian Journal of Soil Research 36, 509-523.

Watt TA, Haggar RJ (1980) The effect of height of water table on the growth of Holcus Lanatus with reference to Lolium perenne. Journal of Applied Ecology 17, 423-430.

White RE, Helyar KR, Ridley AM, Chen D, Heng LK, Evans J, Fisher R, Hirth JR, Mele PM, Morrison GR, Cresswell HP, Paydar Z, Dunin FX, Dove H, Simpson RJ (2000) Soil factors affecting the sustainability and productivity of perennial and annual pastures in the high rainfall zone of south-eastern Australia. Australian Journal of Experimental Agriculture 40, 267-283.

Whitfield DM (1996) Soil water measures in pasture management for water control. In 'Perennial pastures for recharge control'. Report on a workshop, 20-21 July 1995. (Eds J Taylor, C Clifton, A Ridley, P Schroder) pp. 35-38. (Centre for Land Protection Research: Bendigo, Vic.)

Whitfield DM, Newton PJ, Feehan TK (1993) Agronomic vegetation options for dryland salinity management. In 'A National Conference: land management for dryland salinity control'. pp. 54-59. (La Trobe University: Bendigo, Vic.)

Williamson DR, Gates GWB, Robinson G, Linke GK, Seker MP, Evans MR (1997) Salt trends. Dryland Technical Report No. 1. Murray-Darling Basin Commission, Canberra, ACT.

de Wit CT (1958) 'Transpiration and crop yields. No. 64.6.' p. 88. (Institute of Biological and Chemical Research on Field Crops and Herbage: Wageningen, The Netherlands)

Wright J (1988) Daily and seasonal evapotranspiration and yield of irrigated alfalfa in southern Idaho. Agronomy Journal 80, 662-669.

Manuscript received 16 May 2002, accepted 8 May 2003 